655), z którą związany był cesarz Julian Apostata, tylko pogłębiła tendencje magiczne i irracjonalistyczne, zapoczątkowane przez szkołę syryjską. Szkoła ateńska (s. 656-679), wydała jednego wybitnego myśliciela, którym był Proklos (s. 660-677); omówione zostają jego skomplikowany system hipostaz i koncepcja trzech faz procesu powstawania rzeczy (monē, proodos, epistrofē). Wreszcie druga szkoła aleksandryjska (s. 680-685) oraz myśliciele działający na łacińskim Zachodzie świadczą ostatecznie o wyczerpaniu energii spekulatywnych pogańskiego neoplatonizmu, myśliciele tej szkoły ograniczają się do komentowania dorobku przeszłości, wytwarzają typ kultury erudycyjnej i encyklopedycznej, ważnej nie ze względu na własne oryginalne osiągnięcia, ale ze względu na to, że przekazuje ona epoce następnej wartości wypracowane przez starożytność pogańską. Jak pięknie pisze autor: „ «Drugie żeglowanie» zakończyło się już dawno, a rozpoczęło się [... ...] to, co można by nazwać «trzecim żeglowaniem», tzn. kulturą umysłową, rozwijaną w oparciu o orędzie chrześcijańskie" (s. 691). Jak pieczęć zamyka tom IV krótki rozdział dotyczący edyktu Justyniana i losów neoplatoników ateńskich, podróżujących do Persji na dwór Chosroesa (s. 688-692).

Wypada zaznaczyć, że przy cytatach ze starożytnych źródeł i tekstów filozoficznych, którymi autor często i obszernie dokumentuje swoje wywody, Tłumacz posłużył się istniejącymi przekładami na język polski, o ile takowe były dostępne, rzadko opatrując je modyfikacjami, co zaznacza w przypisach. Oryginalne przekłady cytatów z greki na język polski są dziełem Marcina Podbielskiego, przekłady zaś cytatów łacińskich opracował sam tłumacz. Książkę ozdabiają ilustracje: 11 podobizn filozofów, w tym mało znane podobizny prawdopodobnie Plotyna z Muzeum w Ostii, oraz rzeźby portretowe z Muzeum w Atenach, a także fotokopie stron tytułowych ważnych publikacji historycznofilozoficznych, dotyczących omawianego autora bądź szkoły. Barwna okładka, podobnie jak w poprzednich tomach Historii filozofii starożytnej, ukazuje fragment Szkoły Ateńskiej Rafaela. Objaśnienie, co do postaci na okładce, znajdzie Czytelnik na ostatniej stronie książki.

Roman Majeran - Lublin

\title{
Wincenty MYSZOR, Europa: pierwotne chrześcijaństwo, idee i życie społeczne chrześcijan (II i III w.), Warszawa 1999/2000, Studium Generale Europa, ss. 252.
}

Najnowsza książka Wincentego Myszora Europa: pierwotne chrześcijaństwo ukazała się jako siódmy z kolei tom serii „Relectiones”, poświęconej „kulturowym, prawnym, społecznym i teologicznym aspektom integracji euro- 
pejskiej". Jej tematem są wybrane zagadnienia z historii społecznej pierwotnego chrześcijaństwa w II i III wieku w Cesarstwie Rzymskim. Problematyka ta jest ciągle słabo obecna w literaturze przedmiotu, omawiana jest raczej marginalnie i fragmentarycznie. Głównym powodem są źródła; chrześcijańscy pisarze starożytni zajmowali się bowiem przede wszystkim życiem religijnym swoich współwyznawców, zaś o ich działalności społecznej pisali wybiórczo, pomijając całkowicie niektóre formy aktywności w tej dziedzinie. A jeśli spotykamy takie wypowiedzi, to znajdują się one w pismach polemicznych i apologetycznych, przez co ich wartość jest mało obiektywna. Z tych m.in. powodów W. Myszor wątpi w możliwość całościowego opracowania zagadnień społecznych tego okresu (temat ten podejmuje szczegółowo w artykule - Czy możliwa jest historia spoteczna pierwotnego chrześcijaństwa II i III wieku?, w: Kościót socjologia - statystyka. Księga Jubileuszowa poświęcona Księdzu prof. Witoldowi Zdaniewiczowi SAC, Warszawa 1999, 211-217). Mimo wspomnianych trudności dokonuje jednak poważnego wysiłku, by dotrzeć do możliwie największej ilości źródeł świadczących o społecznej działalności chrześcijan. Efektem tych poszukiwań jest kilkadziesiąt wybranych tekstów na ten temat (dokładnie 203). Ich udostępnienie stało się - jak podkreśla sam autor - podstawowym celem książki (por. s. 7).

Teksty pochodzą przede wszystkim z pism teologicznych i z kościelnych dokumentów prawnych (ustaleń synodów), a wypowiedzi pisarzy pogańskich (Tacyt, Pliniusz, Porfiriusz) cytowane są sporadycznie. Większość fragmentów ukazuje się po raz pierwszy po polsku i jest przekładem autora, pozostałe zostały zaczerpnięte $\mathrm{z}$ polskich tłumaczeń tekstów źródłowych (m.in. z POK, PSP). Na podkreślenie zasługuje niezwykła dbałość autora o wierność oryginałowi. W przypadku, gdy w zamieszczonym w wyborze fragmencie (dotyczy to tekstów przetłumaczonych wcześniej) dopuszczona jest jakaś zmiana, pominięte zostało jakieś określenie lub fraza, autor uzupełnia przekład, podając o tym informację w przypisie (zob. m.in. frag. 36, s. 58; frag. 90, s. 113; frag. 111, s. 132). Trudną lekturę źródeł ułatwiają noty komentujące poszczególne fragmenty, systematyzacja tekstów według tematów, które omawiają, oraz studia wprowadzające w poszczególne zagadnienia.

Autor wyodrębnia kilka podstawowych tematów. Są to: stosunek chrześcijan do państwa, obowiązków obywatelskich (np. służby wojskowej), kwestii klasowych, a także organizacja życia religijno-społecznego, ze szczególnym uwzględnieniem problematyki związanej $\mathrm{z}$ rolą kobiet $\mathrm{w}$ chrześcijaństwie, z małżeństwem i rodziną, z działalnością charytatywną, zawodową i edukacyjną, $\mathrm{z}$ aktywnością kulturalną i rekreacyjną. Większość $\mathrm{z}$ nich autor omawiał już w artykułach wcześniej publikowanych (zob. s. 8, przyp. 2), tutaj pojawiają się one jednak w nowym ujęciu. Natomiast zagadnienia dotyczące stosunku do niewolników, organizowania wypoczynku i rozrywki zostały podjęte po raz pierwszy. 
W problematykę społeczną wprowadza rozdział Chrześcijanie $w$ ocenie państwa rzymskiego i współobywateli (s. 9-61), charakteryzujący nastroje polityczne i społeczne, jakie towarzyszyły chrześcijanom na przestrzeni ponad 200 lat; ilustrują je fragmenty edyktów i reskryptów oraz prywatnych wypowiedzi autorów pogańskich (Celsus, Eliusz Arystydes, Porfiriusz). Pozwalają one lepiej zrozumieć działania i reakcje samych chrześcijan (np. źródła ich społecznej i religijnej izolacji, czy tonu mów polemicznych). Z kolei stosunek chrześcijan do państwa i kwestii społecznych przedstawia rozdział drugi (Chrześcijanie wobec państwa $i$ życia politycznego, s. 62-98). Stosunek ten - jak pokazuje autor - był wyrazem określonej postawy religijnej: „Chrześcijanie - czytamy we wprowadzeniu - odrzucili wprawdzie uzasadnienie władzy cesarza, zwłaszcza władzy konkretnej, kultem religijnym. Natomiast przyjmowali ideę, że władza jako taka pochodzi od Boga, należy do porządku rządów nad światem, jest istotnym elementem uporządkowania życia społecznego. Posłuszeństwo wobec władcy jest wyrazem czci dla Boga. Posłuszeństwo wyklucza wszelki aktywny opór, nawet gdy władza jest niesprawiedliwa i niemoralna" (s. 63). Argumentację religijną wzmacniały idee historiozoficzne, przypisujące państwu rzymskiemu szczególną rolę w dziejach (rola tzw. „siły powstrzymującej" nadejście Antychrysta przed końcem świata - por. frag. 55-57, s. 80-84). Chrześcijanie okazują się zatem lojalnymi obywatelami, respektującymi prawny i polityczny porządek państwa, jednakże - jak to wcześniej autor wykazuje ich koncepcja lojalności wobec cesarstwa, silnie motywowana religijnie, różni się od pogańskiej (zob. s. 15). Ilustrują to dobrze (omawiane w poprzednim rozdziale) wydarzenia z czasów Decjusza, gdy odmówili oni (właśnie z powodów religijnych) udziału w powszechnej supplicatio ture et vino za pomyślność cesarstwa oraz indywidualne przypadki odmawiania (z tych samych powodów) służby wojskowej oraz walki; zostały one omówione szczegółowo w rozdziale trzecim: Chrześcijanie wobec stużby wojskowej (s. 99-118). Argumentami religijnymi chrześcijanie posługiwali się również w kwestiach dotyczących niewolnictwa, co ukazuje rozdział: Chrześcijanie wobec niewolników (s. 119-133). „Posłuszeństwo niewolników wobec pana - zauważa autor - służyło za przykład stosunku wiernego wobec Boga" (s. 125), dlatego też niewolnictwo było przez chrześcijan, jako zastana struktura społeczna świata antycznego, akceptowane. Pisarze patrystyczni (Didache, Ignacy Antiocheński) wzywali jedynie do bardziej humanitarnego traktowania niewolników, ale nie wykluczali również (m.in. z powodów religijnych) karania fizycznego (chłosta jako forma ćwiczenia ciała - Tertulian).

Odmienną problematykę przynosi natomiast rozdział: Kobieta $w$ gminie chrześcijańskiej (s. 134-158). Analiza tego zagadnienia, przedstawiona we wprowadzeniu, wskazuje na wiele ciekawych zjawisk dotyczących roli kobiet w Kościele, zwłaszcza w II wieku. Teksty źródłowe wskazują na to, że stanowiły one początkowo grupę liczniejszą i bardziej aktywną niż mężczyźni. Autor pyta 
zatem, czy poważny udział kobiet w rozszerzaniu chrześcijaństwa łączył się z dążeniem do ich równouprawnienia (s. 138). W odpowiedzi wskazuje na „pewną niejednoznaczność” rozstrzygnięć; sam jednak skłania się do przyjęcia modelu oikos (domu), gdzie biskup występuje jako ojciec, ,któremu podporządkowane są pozostałe struktury domu" (s. 141). W dalszej części autor omawia zagadnienie instytucjonalizacji życia kobiet, charakteryzując trzy kategorie: wdowy, dziewice i diakonisy. Dwa kolejne rozdziały poświęcone zostały problematyce małżeńskiej. Pierwszy - Matżeństwo i rozwód (s. 159-182) przedstawia zagadnienia monogamii, cudzołóstwa oraz powtórnego małżeństwa zawieranego w wyniku rozwodu lub na skutek śmierci współmałżonka, podaje też prawno-moralne oraz teologiczne rozwiązania tych kwestii. Drugi Matżeństwo i rodzina (s. 183-196) - omawia zadania chrześcijańskich małżonków (np. prokreacji) oraz problemy małzeństw mieszanych (np. chrześcijanki $\mathrm{z}$ poganinem), przerywania ciąży i porzucania dzieci, a także prawną ich regulację (synody w Elwirze, Ancyrze i Arles). Interesujące są trzy ostatnie rozdziały, które zawierają wiele cennych informacji dotyczących życia codziennego pierwotnych chrześcijan. Materiały źródłowe pozwalają autorowi wyodrębnić m.in. takie kwestie jak: praca oraz zawody wykonywane, stosunek do pieniądza i dóbr materialnych (Praca i zawód, s. 197-212), nauka i organizacja szkolnictwa, odniesienie do kulturowego dziedzictwa antyku, zwłaszcza filozofii, literatury i teatru (Wyksztatcenie, kultura i rozrywki, s. 213-232) wreszcie formy pomocy biednym i potrzebującym (ze szczególnym uwzględnieniem genezy caritas christiana) kierowanej do wdów - które od samego początku były otaczane przez Kościół opieką - sierot, więźniów i niewolników, a także chorych i ludzi starszych (Chrześcijanie wobec biednych i potrzebujących pomocy, s. 233244); szkoda jedynie, że cezura czasowa nie pozwoliła autorowi wspomnieć o opiece, jaką chrześcijanie otaczali ubogich podróżnych i pielgrzymów (ta forma pomocy zaczęła rozwijać się dopiero od IV w. - zob. S. Longosz, Ksenodochium - hospicjum wczesnochrześcijańskie, VoxP 16:1996, z. 30-31, 275-336).

W podsumowaniu należy podkreślić, iż W. Myszor dokonał wyboru tekstów, które bogato dokumentują nie tylko postawy społeczne chrześcijan w II i III wieku, ale świadczą również o istnieniu refleksji religijnej na ten temat. We wstępach do poszczególnych tekstów analizuje wielorakie związki omawianych zjawisk ze światem zewnętrznym, wskazując na ich konteksty polityczno-ekonomiczne, społeczno-prawne, kulturowo-religijne, a nawet filozoficzno-teologiczne (jedne zostały omówione dokładniej, inne są jedynie zasygnalizowane). Dzięki tak szerokiemu tłu praca, będąca z założenia antologią tekstów omawiających życie społeczne chrześcijan, staje się zarazem studium skomplikowanych relacji pomiędzy dwoma społecznościami, chrześcijańską i pogańską (ich konfrontacji oraz wzajemnych wpływów). Dlatego też stanowi interesujący przyczynek do badań nad chrystianizacją pogańskiego społeczeństwa w II i III wieku. Ze względu na bogaty wybór źródeł książka może być polecana 
jako materiał pomocniczy dla prowadzących ćwiczenia z patrologii lub historii wczesnego chrześcijaństwa oraz jako lektura dla studentów. Zainteresować może również szerszy krąg czytelników, np. etyków i filozofów kultury.

\section{Anna Z. Zmorzanka - Lublin}

\section{Jolanta M. MARSZALSKA, Katalog inkunabutów biblioteki Wyż- szego Seminarium Duchownego w Tarnowie, Tarnów 1997, Wyższe Seminarium Duchowne w Tarnowie, ss. 154.}

Stosunkowo rzadko pojawiają się na półkach księgarskich publikacje wymagające długiego, żmudnego i fachowego trudu, ale wydobywające na światło dzienne niekiedy najcenniejsze perły z głębokich zasobów przyklasztornych i kościelnych bibliotek; chodzi tu o starodruki, a zwłaszcza o druki tłoczone przed 1500 rokiem, zwane inkunabułami. Ich ukazana zawartość, proweniencja i obieg informują nas czym, gdzie i kto umiejący wówczas czytać karmił się intelektualnie i dzielił z innymi zaczerpniętą z nich wiedzą. Taką cenną pozycją jest niewątpliwie opublikowany przed dwoma laty w Tarnowie Katalog inkunabułów biblioteki Wyższego Seminarium Duchownego w Tarnowie w opracowaniu p. dr Jolanty Marszalskiej, znanej specjalistki od starodruków i historii biblioteki rodowej Sanguszków. Już sam spis treści katalogu wskazuje na fachowe i wszechstronne opracowanie. Centralną jego część (s. 29-86) stanowi ułożony alfabetycznie autorami wykaz 146 inkunabułów w opisie bibliograficznym, zaczerpniętym z centralnego katalogu inkunabułów w Polsce (Incunabula quae in bibliothecis Poloniae asservantur, t. 1-2, Wrocław 1970-1973), opracowanego przez Marię Bohomos i Elizę Szandorowską, z dodaną charakterystyką każdego opisywanego egzemplarza, w której najbardziej nas interesują podawane in extenso proweniencje. Wynika $\mathrm{z}$ nich, że ponad $60 \mathrm{z}$ wymienionych inkunabułów pochodzi z biblioteki Ojców Benedyktynów w Tyńcu, skąd po kasacie tamtejszego klasztoru (r. 1816) trafiły do biblioteki tarnowskiego Wyższego Seminarium Duchownego w 1838 roku. Pozostałe inkunabuły pochodzą z kolegiackiej biblioteki w Wojniczu, z bibliotek kościołów parafialnych w Bieczu i Czchowie, oraz kolegiat nowosądeckiej i tarnowskiej. Znawca starej książki łatwo zauważy w tej kolekcji 19 inkunabułów w skali krajowej, wśród nich 2 unikaty w skali europejskiej (nr 86-87) autorstwa Joannesa de Garlandia: Composita verborum cum commento Joannis Synthen. (Deventer ok. r. 1492) i Verba deponentialia cum commento Joannis Synthen. (Deventer po r. 1485), obydwa pochodzace z biblioteki tynieckiej. Najstarszym tarnowskim inkunabułem jest Catholicon Joannesa Balbusa ( $\mathrm{nr} 16)$ ze strasburskiej typografii Adolfa Ruscha, również ze zbiorów tynieckich. $\mathrm{Z}$ tychże zbiorów pochodzą również inne najstarsze inkunabuły tarnowskie, ,które bezsprzecznie na- 